\title{
KITEKINTŐ
}

\section{PARIS LA DÉFENSE}

\section{DARÓCZI ETELKA}

Párizs örök, mert folyton újjászületik. Nem a múlt ma is bámulatba ejtố emlékeinek gondos ốrzése teszi a városok városává, hanem a szüntelen lüktetô, nyughatatlan élet. Az évszázados örökség megannyi látványos értéke ehhez ,,mindössze” elôjáték és kútfổ, vagy éppen csak díszletül szolgál. A város mérete sem több, mint egy a temérdek, megfoghatatlan teremtố közül, amely a ,, hely szellemét" alakítja. Párizs hétköznapjain (vagyis amikor lakói többen vannak, mint látogatói) megállíthatatlanul áramlik, türelmetlenül nyüzsög, és folyton berzenkedik. Az utcai rohanást még hajlamos lenne a szemlélô a nappali népesség számával összefüggésbe hozni, de azt kellett tapasztalnom, hogy a párizsi tempót az általam ismert világ nagyvárosai (szerencsére?) nem tudják felülmúlni. A legnagyobb meglepetés New Yorkban ért, ahol a jármúvek és gyalogosok viszonyát - legalábbis a budapestihez vagy a párizsihoz képest - kisvárosian kedélyesnek, sốt szívélyesnek találtam. Igen, ha Budapest architektúrájában Bécsre hasonlít is, hangulatában több a párizsi vonás. Talán közös izgágaságunk, örökös elégedetlenségünk az oka, meg hogy hamar fölcsattanunk és szívesen kioktatunk másokat. Ezek persze nem a leglényegibb néplélektani vonások. A mélyebb rétegekben valószínúleg a különbségek kerülnének elô; a rég- és a közelmúltban bejárt eltérô utakból, az ég és föld viszonyával jellemezhetố jeienlegi helyzetünkbớl fakadó különbségek. A franciák nemcsak büszkék és újító szándékúak (mint talán mi is vagyunk), hanem bátrak, bíznak önmagukban, teremtố fantáziájukban, a szabad szellem és a szabad lélek erejében (még mi legfeljebb merïnk szabadon gondolkodni), a rajtuk (is) múló megismerhetôségben, megváltoztathatóságban és jobbításban. Az a benyomásom, hogy a jó és a szép belsố ragyogását a franciák szemében nem homályosította el a pénz talmi fénye, a szerzés mámora. Hisznek, és nemcsak a tulajdonban és a tốkében (vagy egy korábbi ellentéttel élve: nemcsak az ideológiában és az értéktermelố munkában), hanem az általánosabb, s ezért maradandó értékekben - a szellemben, a mưvészetben - azaz nemcsak a piacban, hanem - uram bocsá' - a használati (legtágabb értelmében a humán) értékben. Természetesen tudatában vannak kiválóságuknak, hogy ma is ốk az európai kultúra fellegvára (tân a kultúra letéteményeseinek is gondolják magukat, ahogy Amerika a szabadságénak), s ezt akarva-akaratlan éreztetik, és világgá kürtölik.

E leegyszerüsítő és szubjektív általánositások, kellổen fel nem róható eloóitéletek húsz év alatt - nem sứrú, de többszöri párizsi utazásaim hatására - halmozódtak föl bennem. Mindaddig nem fogalmazódtak azonban meg, míg nem , észlelhettem" a francia forradalom 200 éves évfordulóját ünnepelni készülô, magát méginkább kitárni vágyó, lázas állapotában még jellegzetesebb (vonzóbb és taszitóbb), rendkívüli asszony-várost. A szoknyája szélén kapaszkodó városcsemete, a La Défense többek között egy moder diadalív (a térképen a 7-es szektorban látható La Grande Arche, azaz A Nagy Ív) felavatásával ünnepelt. 


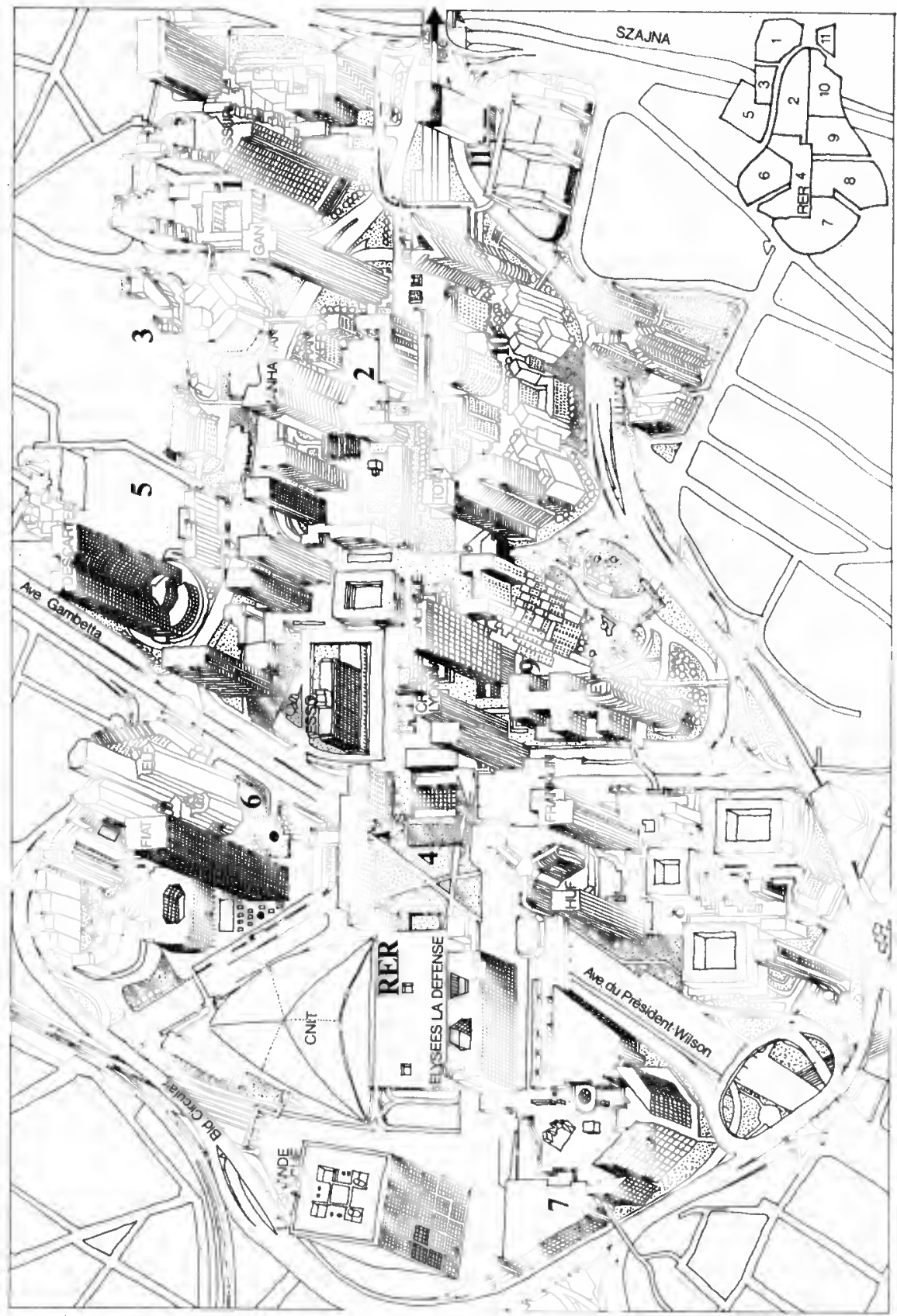

A La Défense üzleti negyedének II szektora

Nagy Béla rajza (az EPAD eredeti térképe alapján és szíves hozzájárulásával, amelyet ezúton is köszönünk) 


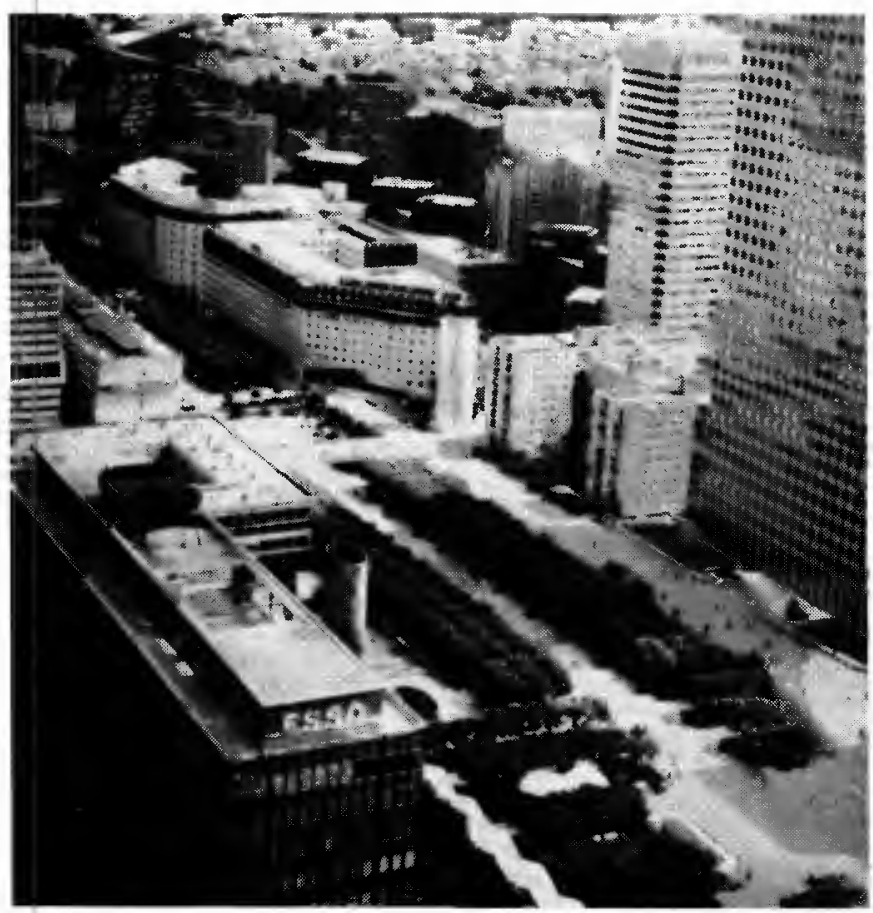

\section{KÉP}

A , széduletesen hallgatag" sugárut a FIAT felhókarcolojának 46. emeletérol, az EPAD kiallitótermének ablakából. Elótérben az ESso székháza, a legelsó a La Défense területén. Elsớ generációs épulet, jóval a gyalogosforgalmat tartó dobogó elkészulte elött, 1963-ban adták at. Vele szemben a 36 emeletes, masodik generációs Generale (1975).

Hattérben a Bois de Boulogne, a bal folsó sarokban az Eiffel torony és a Montparnasse felhokarcolo.

\section{KÉP}

Második és harmadik generációs toromyházak balról jobbra:

Franklin (1972), SCOR (1983), Winterthur (1974), mögötte a Residence de La Défense (belsó udvarral) és a Défense $2000 \mathrm{fel}$ hókarcolo. Mellettik még látható a dobogó alá merilló autóforgalom. Elötérben a Négy Évszak bevásárlóközpont felulnézetbol.

A szerzó felvételei

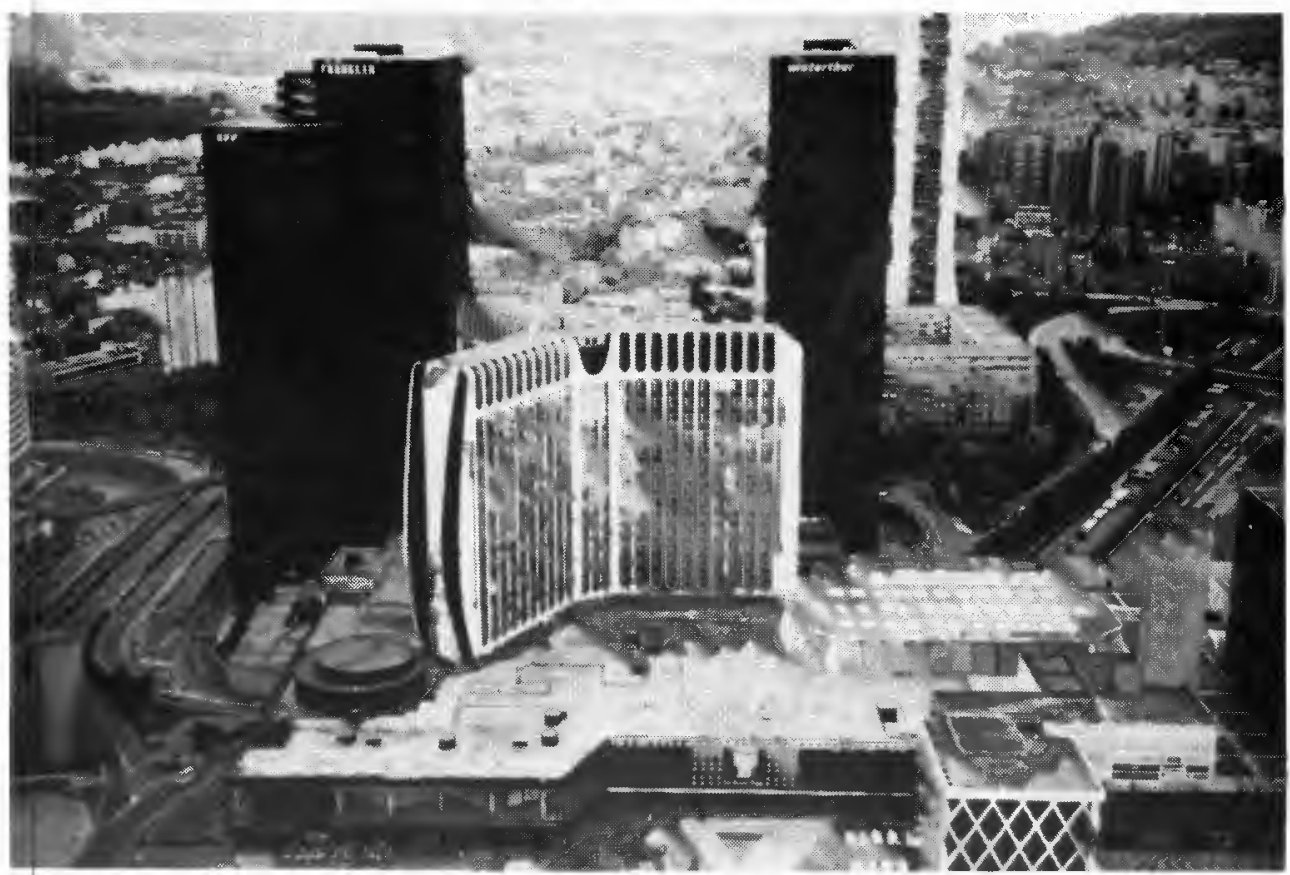


A tercierváros La Défense tulajdonképpen kívül esik Párizs közigazgatási területén' ${ }^{1}$, Courbevoie, Nanterre és Puteaux határában fekszik, de ennek semmi jelentôsége. $S$ ha mégis, mindenféle rafinériával igyekeznek azt csökkenteni: például a központi épületek tulajdonosai/bérlổi használhatják a ,,Paris La Défense” postacímet. Végtére ez nem csalás, nem ámítás, hiszen a La Défense Párizs legổsibb, legnevezetesebb tengelyének (Notre Dame - Louvre - ChampsElysées - Diadalív) északnyugati meghosszabbításában jött létre. ${ }^{2}$

Nevét az 1870 -es porosz megszállás párizsi hőseinek tiszteletére emelt emlékmüroôl ${ }^{3}$ kapta, amely egykori (Etoile-méretû́) köröndjének közepén állt. E két hatalmas körtér (az Etoile és a Rond-point de la Défense) közötti útvonal építészeti, funkcionális és egyben emlékmũ célját is szolgáló rendezésére Párizs városa 1931-ben tervpályázatot írt ki. A 35 építészeti megoldás egyike sem elégítette ki a zsû́rit; a monumentalizmus dominált, az esztétikus funkcionalizmus háttérbe szorult. A Citibank ekkortájt fogant ötlete egy világkereskedelmi központ létrehozására és Le Corbusier pályázati elképzelése a jármú- és gyalogosforgalom szétválasztására mindenesetre meghatározónak bizonyult a városrész 20-50 év múlva bekövetkezõ jövôjére. Mérföldkő volt - ha nem is valósult meg - a nemzetgyũlés 1946 (!)-ban elốterjesztett javaslata: rendezzenek világkiállítást a Défense-ban. Az elképzelést a háború utáni újjáépités sürgôssége és nehézségei miatt egy állandó kiállítási palota tervére egyszerüsítették. A Nemzeti Ipari és Mû́szaki Központ (Centre National des Industries et des Techniques, CNIT) építési engedélyét 1954-ben adják ki, és a világszerte bámulatot kiváltó hatalmas csarnokot 1958-ban avatják fel. (A térképen a 4-es szektorban található.) Ugyanebben az évben alakul az EPAD (Közintézmény a La Défense Régió Területrendezésére) 11 fôvel. (1989-ben 255 munkatársa volt.) Nevében foglalt feladata a javaslatok kidolgozásától vagy véleményezésétôl az irányításon és összehangoláson, a program valamennyi részvevôjével - a bádogházakban lakókkal, a kistulajdonosokkal, a tervezőkkel vagy a világcégekkel - folytatott tárgyalásokon át a kivitelezésig terjed. Igazgatója, André Prothin az államtól 30 évre szóló megbízást és 30 millió frank megelốlegezett indulótốkét kap a városrész létrehozására az ekkor kijelölt 760 hektárnyi területen.

A városrész elsỗ rendezési tervét - amelyet a CNIT tervezôi 1950-ben készítettek, és amelyet átdolgozás után 1956-ban hagytak jóvá - az EPAD elvetette. Több menetben $(1959,1964,1969)$ folyt a tervezés-elfogadás-elvetés-újratervezés, a La Défense nagy szerencséjére. Így sikerült elkerülni az egyszerre véglegesre tervezésbốl szinte szükségszerũen adódó monotóniát. (Az 1956-ban elfogadott terv például a moszkvai Kalinyin Sugárút képére formálta volna a városrészt.) A jármũvek és a gyalogosok teljes szétválasztását egy 40 hektárnyi ,,dobogó" megépítésével oldották meg; ez köti össze az épületeket, dobogón járnak az emberek, nônek a fák, és zuhognak a szökôkutak, $s$ alattuk hat szinten zajlik a közúti közlekedés, áramlik a fútés és mindenféle vonalas létesítmény (1-2. kép).

A kereslet növekedése és a magasépítés technológiajának korszerúsödése lehetốvé tette, hogy a bevételek növelése céljából 1969-ben 100 m-rớl 200-ra emeljék a megengedett épületmagasságot. A gyorsvasút (RER) (4-es szektor) állomásának megnyitása 1970-ben ugrásszerưen megnövelte az érdeklổdést. Megkezdôdött a toronyházak második (amerikai típusú) generációjának, a GAN (biztosító, 2-es szektor), az UAP (viszontbiztosító az ASSUR felhốkarcolóban, 1-es szektor), a FIAT (6-os szektor) stb. székházának építése. Itt jegyzendố meg, hogy az EPAD a szolgáltatások után fizetett járandóságból és az építési jog eladásából fedezi a városrendezés, az infrastruktúra, a parkosítás, a mũalkotások stb. költségeit. Az építési engedély nem földterületre 
vonatkozik (hiszen a talaj felszínén, az alatt és fölött már az építkezés megkezdése elôtt több rétegben zajlik az élet), hanem a beépíthetô légköbméterre .

A mélyreható változásokat jellemzi, hogy 32 ezer lakost kellett - minden esetet külön tárgyalva - kártalanítani, illetve elhelyezni, 415 hektárnyi, ezernyi telekre osztott területet kisajátítani, 500 mühelyt és 570 kereskedést sürgôsen áthelyezni. (Sổt, a CNIT lábánál 1959-ben még istálló is volt, nyolc fejôstehénnel...) Nem tudom, készült-e legalább utólagos kỏzvéleménykutatás a lakosság körében arról, hogyan élték meg ezt a nagy föld-fordulást. (A pánik és az ellenállás elkerülése, s nyilván a költségek csökkentése végett elổzetesen biztos nem szellổztették a terveket. A felmérést végzố gyakran a gázmưvek ellenőrének adva ki magát járta a házakat.) Így a másik fél szemszögéból nem lehet megítélni az akkori eseményeket. A tervezốk mindenesetre igen fontosnak tartják hangsúlyozni és dokumentálni, hogy az ott élók lakáskörülményei szegényesek vagy kifejezetten rosszak voltak (hétezren éltek faládákból tákolt viskókban), hogy az egyéni szempontokat messzemenően figyelembe vették, s a gyökérvesztettség és a megrázkódtatások elkerülése végett az új otthonokat a régiektól nem messze építették. A kisajátított ingatlanok bérlői (9500 család) részére HLM (kedvezményes tanácsi) lakásokat adtak át, fớleg Nanterre-ben. A lakosság részvétele a tervezésben, a környezet alakításában majd csak a La Défense válsága után, a nyolcvanas években aktivizálódik.

A válság 1972-ben, a GAN 44 emeletes székházát ért kemény bírálatokkal kezdổik: az épület megszentségtelenítette az addig érintetlen panorámát, a sugárút zavartalan perspektíváját (2-es szektor). De nemcsak errốl volt szó. Az irodaházépítés jövedelmezôsége túltermelést eredményezett Párizsban. Az energiaválság, a környezet- és természetbarát megoldások elỡtérbe kerülése megpecsételte a nyithatatlan ablakú, drága pénzen légkondícionált, tudományos és esztétikai szempontból megalapozottan, de mégiscsak mesterséges fénnyel megvilágított toronyházak sorsát.

A Manhattan nevet viselô felhókarcoló (2-es szektor) hónapokig üresen kesereg, 1973 és 1978 között az EPAD szinte semmit sem értékesít, adóssága 680 millió frankra (indulótớkéjének több mint 22-szeresére) rúg. Az állam (személy szerint $R$. Barre miniszterelnök) további irodaépítés (köztük egy minisztérium) engedélyezésével, a földalatti autópálya folytatásával, parképítéssel, környezetszépítéssel, egy dinamikus vállalkozó pedig (a 34 éves Ch. Pellerin) az ún. harmadik generációs irodaházak kifejlesztésével (humanizált környezet, egyedi kivitel, nyíló ablakok, olcsóbb üzemeltetés) húzza ki a La Défense-t a bajból. A bizalom helyreáll, újra fellendül a forgalom. Az EPAD pénzügyei rendezốdnek, s ma már egy fillérrel sem tartozik az államnak. 1989-ig összesen több mint 21 ezer lakás, több száz céget elhelyezõ 2 millió $\mathrm{m}^{2}$ iroda, 200 ezer $\mathrm{m}^{2}$ kereskedelmi terület és temérdek infrastruktúra épült (3. kép). Az EPAD befektetése 16 milliárd frank (az indulótớke több mint 500-szorosa).

S vajon milyen élményt nyújt ez a jellegzetesen huszadik századi, tudatosan formált, ám a körülmények és az igények szerint rugalmasan változó városrész? Mindenekelốtt lenyứgözốt: francia és idegen ámul és bámul; az épületek nemcsak gazdagok és magabiztosak, hanem szépek, változatosak, merészen ötletesek. Muzeálisan mủvészi környezet, nem olyan, amilyet a saját képére formál az ember. A La Défense elsősorban a munkahely, a cég, az üzlet presztizsét és kiválóságát hivatott hangsúlyozni, nem az ott lakókét. Részadatokból következtetett becslésem szerint 2-2,5-szer annyian dolgoznak itt, mint ahányan laknak. (Párizs közigazgatási területén egyelốre (?) többen laknak, mint ahányan ott dolgoznak.) A La Défense népessége 


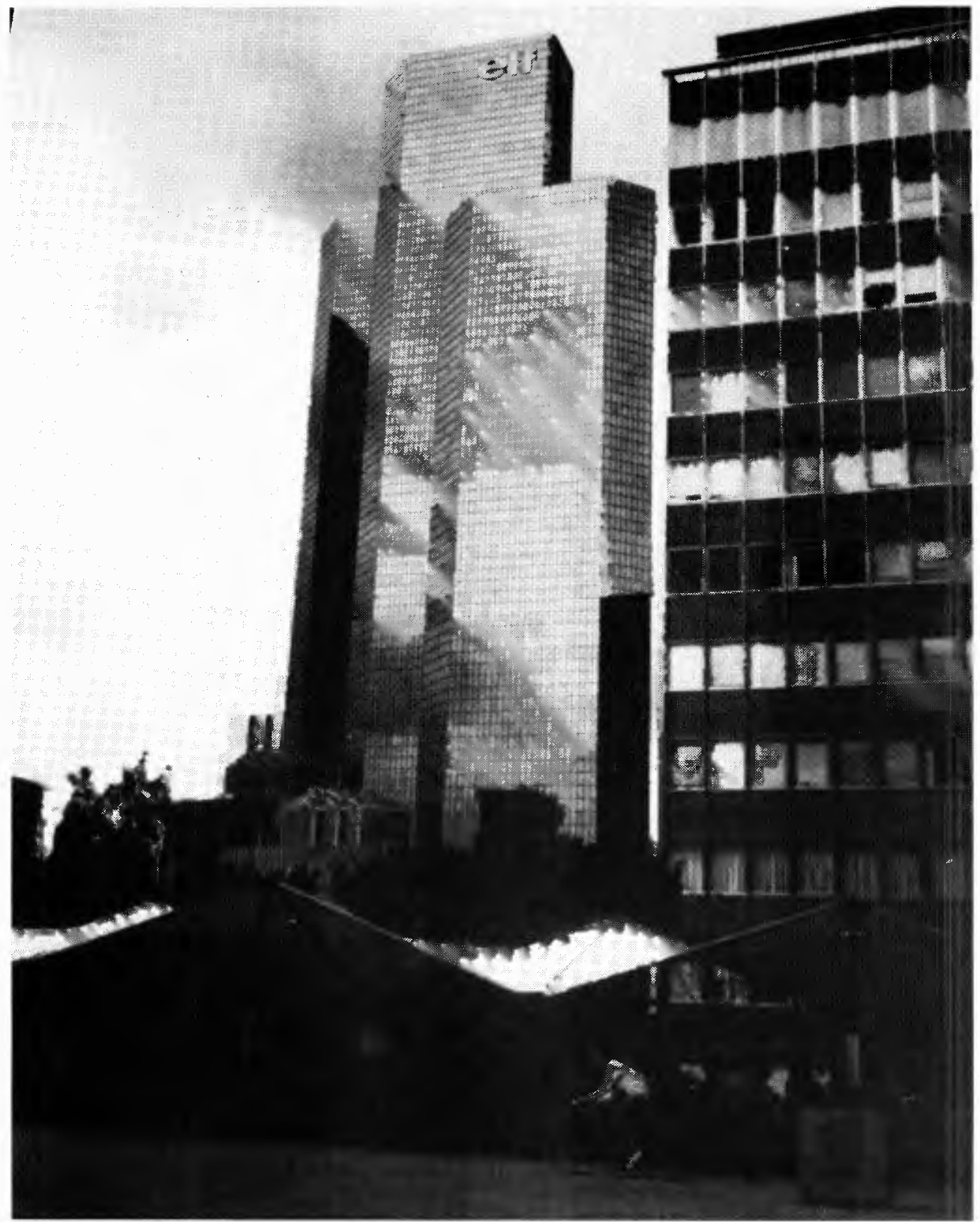

3. KÉP

"Benzinkutasok" vetélkedése: az ESSO mögött az ELF. A 48 emeletes, 1985-ben átadott ELF palota a La Défense büszkesége. 


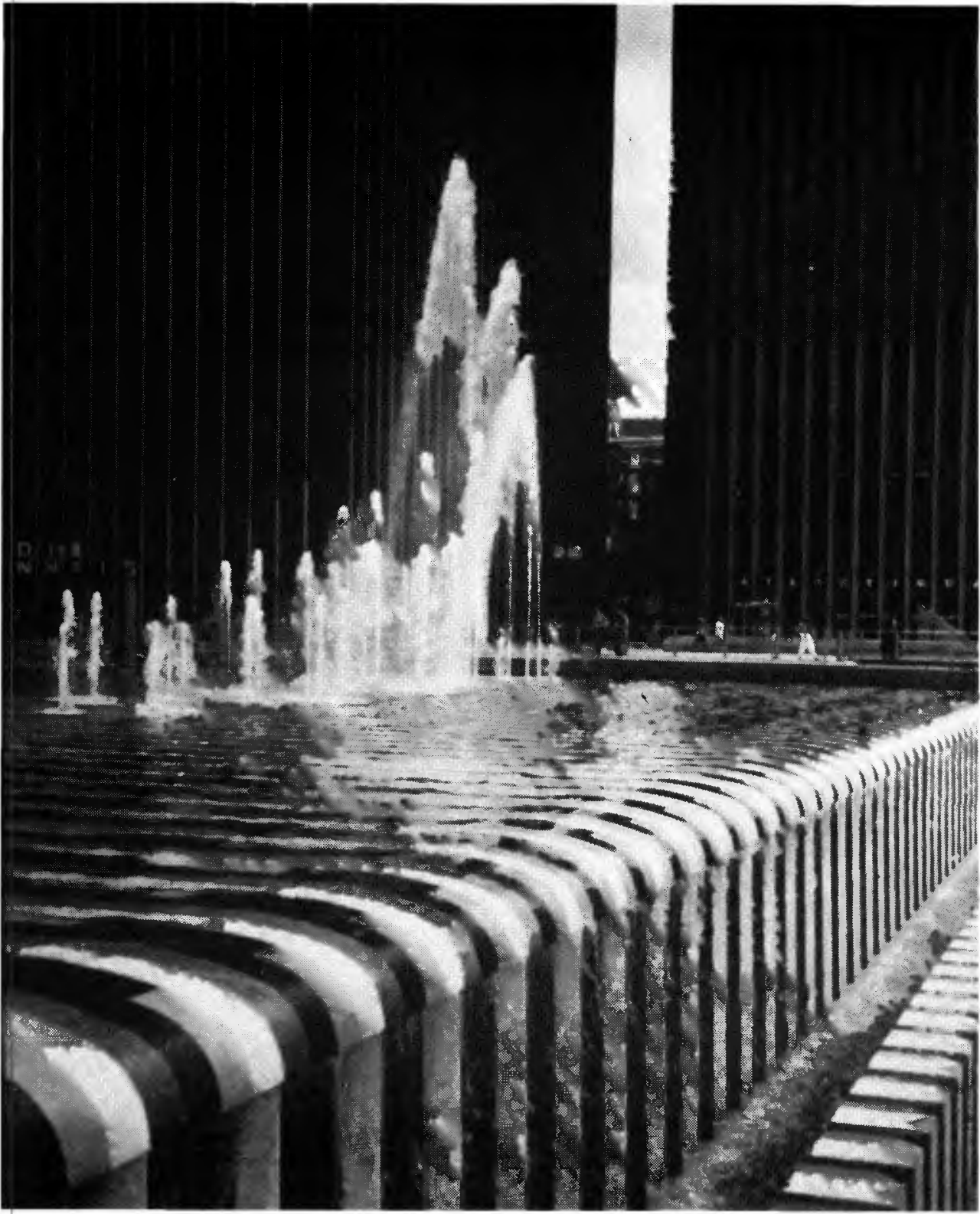

4. KÉP

Tián a legkedveltebb ez az elektronikusan vezérelt szökôkút, Yaacov Agamnak, a kinetikus mũvészet egyik úttöröjének alkotása. A $26 \times 86$ m-es medencéboól kiemelkedó vizoszlopok fényre és zenére ugrálnak vagy perdullnek-fordulnak, zúdulnak, csobognak vagy zuhognak. Háttérben az Atlantique (1970) és a Credit Lyonnais (1973). 
1983-ban hallatja elốször a hangját, de akkor teljes erốvel. 14 ezren vesznek részt az épületfoglalásokban. A parknegyed övezeteinek kialakításáról van szó, arról, mit hova szabad építeni és mit hova nem. A beterjesztett tervet elvetik, majd Nanterre városának és a lakossági egyesületek javaslatainak figyelembe vételével átdolgozzák. A véglegesített változatot két év múlva fogadják el. „Harmadik generációs” HLM lakóházak épülnek: ezeknek a felhốkarcolóknak nincs egyetlen egyenes oldaluk, mindegyik görbül valamerre. Az ablakok szabálytalan alakúak és szanaszét szóródnak a fal domború felületén, amelyet kék bárányfelhốk vagy zöld növényi elemek díszítenek. Az utca is girbe- gurba és csupa hepe-hupa, természetesen nem véletlenül, hanem Emile Ailland alkotó fantáziája szerint. Azt nem tudtam meg, jól érzik-e magukat ,,Bolond Istók tornyai''-nak lakói, de úgy tû̉nik, beletörôdtek sorsukba.

A szigorú architektúrájú üzleti negyed hangulatának javítására - különös tekintettel a teljesen jármũ nélküli, ,,szédületesen hallgatag” széles sugárútra - több állandó és ideiglenes megoldás (?) született. Az utóbbiakhoz a kiállítások, vásárok, hangversenyek, jazz-fesztiválok stb. tartoznak. Parkosítással, hatalmas vízfelületư modern szökốkutakkal - amelyeket sose szórnak tele klórral, mégsem algásodik bennük a víz (4. kép) —és egyéb jelentổs múvészi alkotással igyekeznek nemcsak az üzleti élet, hanem a túristák és a járókelốk vonzalmát is megnyerni, a felhôkarcoló-múzeumba életet lehelni. Jelentôsen hozzájárult ehhez A Négy Évszak (Les Quatre Temps, 4-es szektor) hatal mas bevásárlóközpontjának megnyitása 1981-ben. Bár az épületek közti terek mũvészi kialakítása fokozza a muzeális jelleget, mégis kezd már a La Défense birtokba vehetổ, mindennapos használatra való várossá formálódni. A több mint harminc, általában méretével is kiemelkedố esztétikai térelem - amelyek között a névadó allegórikus szoborcsoport nemigen találja helyét ( 5 . kép) - csaknem mindegyike valamilyen módon kerek, hengeres vagy gömbölyũ, és gyakori a légies megjelenés. Az 1953-ban született Henri de Miller feltehetôen a legifjabb a La Défense számára alkotó mũvészek között. Bronzgömbön egyensúlyozó, nádszálkarcsú nôalakja ("A holdkóros") tipikus példa a hasábokból és kockákból formázott városrész szögleteinek tompítására. A harsány színek, például a már elhunyt nagy öregek, Juan Miro (6. kép) vagy Alexander Calder (7. kép) mũvei, illetve az 1931-ben Budapesten született Atila (sic!) "A felhôszobrász" címû́ tũzzománc freskója szintén az'egyhangúság ellenpontozását szolgálja.

A parkosítás a francia hagyományokat követi. A széles sugárút mentén nyírt platánsor, a pázsit és a virág szigorúan ágyásokba rendezve, bokrokat nemigen látni. Az üzleti negyedben ritkán kerül az ember közvetlen érintkezésbe a növényekkel, pedig vannak, mégpedig óriási erổfeszítés árán, méregdrága mesterséges talajban nônek a betondobogó tetején. Így aztán az utcán nemigen találni egy meghitt szögletet. (Az épületek belsejére ez nem áll, ott a pálmaháztól a leglakályosabb lakosztályig szinte minden megtalálható.) Persze igazi utca sincs, kivéve a fổutcát, a széles, széljárta sugárutat, amely túl széles, 'túl üres, és bizony még többnyire unalmas sétány. Egyelổre. Talán. Hiszen még nem volt végig készen, amikor láttam. Még hátra volt a nagy szenzáció, a város szívébỏl a Champs-Elyséen átvezetô perspektívát szellemesen le-ismeg-nem-is-lezáró emlékmũ-épület, a Nagy Ív (7-es szektor) átadása. Épülôfélben, elsố pillantásra fốleg monumentalitását, rossz emlékeket idézổ, félelmet keltố hatását éreztem (7. kép). A hatalom, a tudás és az erố diadalívét láttam benne, nyomasztott nagysága és szigorúsága. A modern müvészet olvasatában járatlan szemlélöként az érzékeimre hagyatkoztam. Közelítsünk most intellektuálisan. Otto von Spreckelsen dán építész, aki sajnos neṃ élhette meg a mư elkészültét, így vallott tervérôl (Demeyer 1988): 


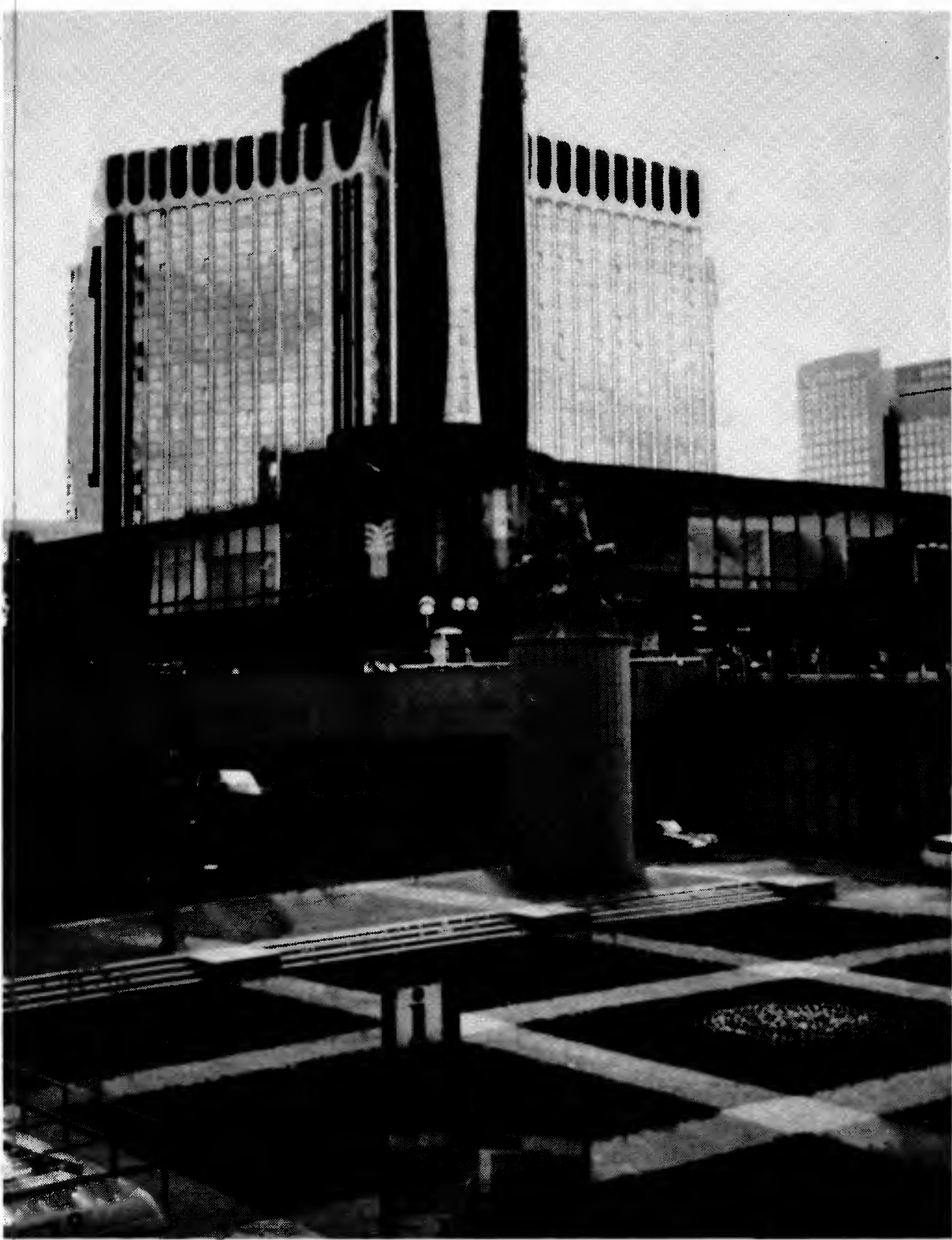

5. KÉP

'Párizs Védelme 1870-ben." Barrias allegórikus szobra az oszlopos talapzaton is szinte elvész a környezetben, pedig müanyagból készitett mása sokáig vándorolt egyik helyrôl a másikra, hogy végleges helyét megtalálja. 


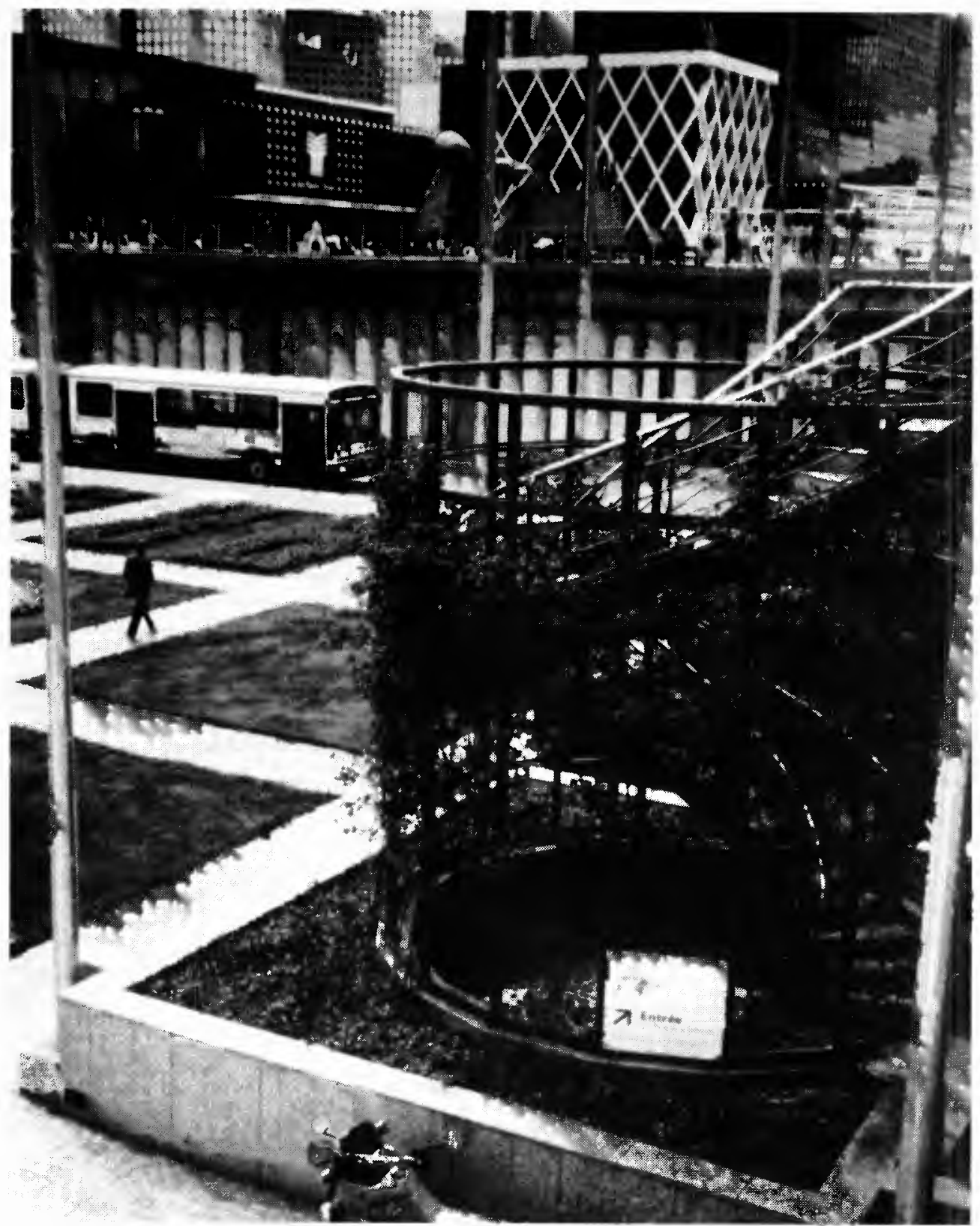

6. KÉP

Intim (?) szöglet. Hättérben az alsó szinten autóbusz jár, fölötte, az oszlopok tartotta pódium a gyalogosaké. A Négy Évszak kereskedelmi központ (1981) bejárata elött Juan Miro 11 és 12 méteres - sajnos a képen alig kivehetó -, rikító piros-kék-sárga müanyag alakjai figurázzák ki környezetük szigoruan szögletes épulleteit. 


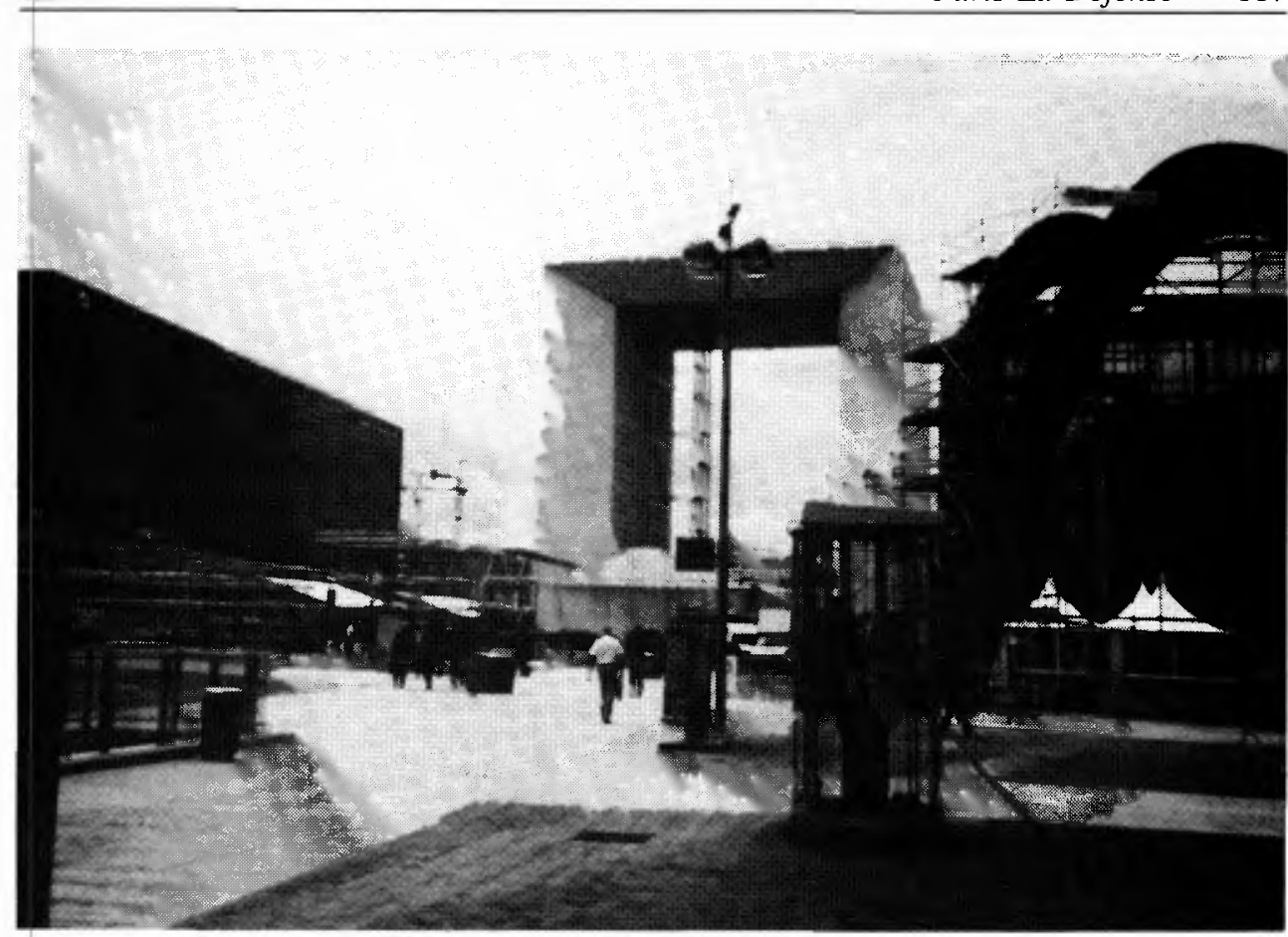

7. KÉP

A Nagy Iv, Otto von Spreckelsen posthumus alkotása átadása elótt egy hónappal (1989). Balra a pálmaházáról nevezetes avegpalota, az Elysées La Défense (1982), a telefonfülke mögött jobbra (az 1976-ban elhunyt) Alexander Calder utolsó müve. A $15 \mathrm{~m}$ magas alkotás a La Défense létrehozásáért fáradozók eltôkéltségét jelképezi.

A szerzo felvétele 
"Nyitott kocka,

Ablak a világra,

Mint ideiglenes orgonapont

a sugárúton,

Tekintete a jövóbe vetve.

Modern diadaliv,

Az emberiség gyốzelmének dicsốségére, amely

$A$ reményt szimbolizálja, hogy a jövóben

Az emberek szabadon találkozhatnak."

Tehát Nagy Fal helyett Nagy Ív. A nemzetközi zsứri 424 jeligés pályázat közül egyhangúlag szavazott a Nagy Ív-re, s Mitterand elnök is ezt választotta. Az épület 35 emeletes (110 m magas), homlokzata ferdén metszett, tükrözổ üvegablakok borítják. Külsô oldalfala carrarai márvány, bélése rozsdamentes fém, üregében felvonók haladnak le s föl. A kocka forma a Diadalívvel, tengelyének 6 fokos eltérése a sugárúttól a Louvre-ral köti össze. Az épület tetején nyilvános panoráma terasz, egyik lábában a Felszerelés- és Lakásügyi Minisztérium. A fennmaradó $40.000 \mathrm{~m}^{2}$-nyi irodahelyiséget , Hírnév és kivételesség” jelszóval hírdetik bérbeadásra tercier vállalatok számára. Világszerte ismert, a Rockefeller és a World Trade Center-ekével pillanatokon belül vetekedố rangot és tekintélyt jelentố címet, kivételes elhelyezkedést, tökéletes mứködést és szolgáltatásokat (pl. 3000 telefonvonalat, belsô információs hálózatot, a belsổ tér teljes átalakíthatóságát a vezetékek érintése nélkül, külön tanulmányozott esztétikai és hangulati hatást) s végül ésszerư költségeket ígér leendổ bérlöinek a prospektus.

Az EPAD müködését - a harminc év elteltével - négy évvel meghosszabbította a kormány. A közeljövố tervei között szerepel a lakossági és idegenforgalmi szolgáltatások színvonalának emelése, az eddig meglehetôsen elhanyagolt földalatti területek rendbe tétele, a CNIT teljes ủjjáépítése, egy Autóváros és egy Játékközpont kialakítása. A CNIT kiállítási csarnokából több rendeltetésư épület lesz. Többek között egy kongresszusi központ, egy luxusszálloda és a professzionista informatika , ,bevásárlóközpontja" kap itt helyet.

A Nagy Ívvel új korszak kezdôdött a La Défense életében, amelynek alakításában a helyi közösségek egyre serényebben vesznek részt. Ennek bizonyságaképp - történetében először - a helybeliek választott képviselôje (Puteaux polgármestere, egyben az Ile de France régió tanácsának alelnöke) került az EPAD élére. Meghosszabbított mandátumának lejárta után az EPAD nem bábáskodik tovább a férfikorba szökkenó városrész fölött. A La Défense búcsút vesz a szakértổ szülöi háztól, és frigyre lép a laikusokkal. E házasság gyümölcseként a szép, de még visszhangos, itt-ott sivár új közös otthon remélhetôleg megtelik élettel, a sok üres térség funkcióra talál, s a spontán mozgások kitöltenek minden zegzugot. Sok szerencsét, La Défense! 


\section{Jegyzetek}

' Párizs közigazgatási területe mindössze $100 \mathrm{~km}^{2}$, amely 5000 blokkra, illetve 80.000 telekre oszlik, 1.280 .000 lakás, 2.176.000 lakos és 1.813.000 munkahely található rajta (az 1982-es népszámlálási adatok szerint). Az adatok forrása: Atelier Parisien d'Urbanisme.

${ }^{2}$ Magára a meghosszabbításra jóval Haussmann elốtt került sor. Az 1772-ben kóhídra váltott pont de Neuilly-t pontosan a Champs-Elysées tengelyében helyezték el, majd a folyó túlsó partján az Etoile átmérôjével azonos nagyságú köröndöt alakítottak ki. Így a Tuileries széles perspektívája végre átívelhetett a kanyargó Szajnán.

${ }^{3}$ Az emlékmũ - Louis-Ernest Barrias (1841-1905) alkotása - a ,,La Défense de Paris en 1870”, azaz „,Párizs védelme 1870-ben" nevet viseli. A városrész neve ("A Védelem") miatt a külföldi kapcsolatokban sokszor adódtak humoros félreértések.

\section{Irodalom}

Atelier Parisien d'Urbanisme (é.n.), Mimeo.

Patrick Demeyer (1988): La Défense. 30 ans, 30 évenements; Paris La Défense: EPAD, 71 o.

EPAD - Brigitte Hedel-Samson (é.n.): Guide to Works of Art in the La Défense District, Paris La Défense: EPAD. EPAD (é.n.): La Défense. Le répertoire des bureaux, Paris La Défense: EPAD, 750.

EPAD (1989): La Défense pratique, Paris La Défense: EPAD (prospektus).

Le prestige et l'exception (é.n.), Paris La Défense: Les Bureaux de la Grande Arche (prospektus).

Les 4 Temps. Le plus grand centre commercial d'Europe (é.n.) (prospektus). 